Printed in Great Britain

\title{
WARM-WATER SPECIES IN THE PLANKTON OFF THE ENGLISH CHANNEL ENTRANCE
}

\author{
By J. H. Fraser, D.Sc. \\ Marine Laboratory, Aberdeen
}

Through the kindness of Dr L. H. N. Cooper of Plymouth I have been given the opportunity of examining some of the plankton samples taken by Surg.-Lt. P. Campbell, R.N.V.R., of H.M.S. Challenger. It is hoped that the results of these and later surveys will be published elsewhere in more detail, and in association with those made by the Scottish research vessels farther north, but two records of unusual interest are brought to notice here. The collections so far examined in detail were taken during April and May 1953, on a line of stations west of the English Channel, from $49^{\circ} 39^{\prime} \mathrm{N}$., $3^{\circ} 30^{\prime} \mathrm{W}$. to $47^{\circ} \mathrm{I} 6^{\prime} \mathrm{N}$., I $7^{\circ} 52^{\prime} \mathrm{W}$. between I5 and I9 April, and on the return line from $47^{\circ} 50^{\prime} \mathrm{N}$., $\mathrm{I} 7^{\circ} 4 \mathrm{O}^{\prime} \mathrm{W}$. to $49^{\circ} 28^{\prime} \mathrm{N}$., $5^{\circ} 52^{\prime} \mathrm{W}$. between 25 and 28 May. They were made by Io min. horizontal hauls at 30 fathoms depth.

On $\mathrm{I} 7$ April I953, at $47^{\circ} 3 \mathrm{I}^{\prime} \mathrm{N}$., I4 $4^{\circ} 2 \mathrm{I}^{\prime} \mathrm{W}$. the plankton contained a rich variety of oceanic species consisting mainly of various Siphonophora. Amongst them were found a single specimen of the solitary form of the salp Ritteriella picteti Apstein, I5 mm. long, and seven specimens of the aggregate form of $R$. amboinensis Apstein, IO-25 mm. long. No other salps were found there.

This specimen of the solitary form of $R$. pictet $i$ has sixteen body muscles, all interrupted on the ventral side, the range for this species being from thirteen to twenty-one or more. It is clearly distinguishable from the solitary form of the closely allied $R$. amboinensis, which usually has only eleven muscles of which the first three are continuous ventrally, but may have from ten to thirteen. There are also other differences, particularly in the form of the gut. The specimen is in excellent condition and was obviously thriving when caught; it is a young one as this species can reach at least $70 \mathrm{~mm}$. in length.

The seven aggregate specimens of Ritteriella found by H.M.S. Challenger have muscle arrangements exactly corresponding to the published description of $R$. amboinensis, including the arrangement of muscle VI which, according to Thompson (1948), is not known in other Ritteriella species or in the Cyclosalpa group. The aggregate form of Ritteriella picteti is imperfectly known. One very small embryo taken from the stolon of a solitary form and figured by Apstein as $R$. amboinensis was later ascribed by Ihle to $R$. retracta, now thought to be synonymous with $R$. picteti. Three small $(3-4 \mathrm{~mm}$.) specimens from Australian waters were ascribed with some doubt to $R$. picteti by Thompson (I948), who also took embryos from the stolon of a solitary 
form. It would appear from Thompson's description to have five dorsally approaching muscles, as in Salpa cylindrica, and would thus be sufficiently distinct from that of Ritteriella amboinensis to make recognition possible. These Challenger specimens are in quite good condition, and their identification as $R$. amboinensis and not $R$. picteti would, according to this, seem reliable, although more work and material is required before the relationship between these species can be adequately understood.

Both these species are considered to be equatorial and are regarded as rather rare even there, especially $R$. picteti. Both occur in the Pacific Ocean, particularly in the neighbourhood of the East Indies and Philippines, and in the Indian Ocean. R. amboinensis has been recorded in the equatorial and southern Atlantic, off the coast of Africa, but because of a confusion in synonymy it is doubtful if $R$. picteti has yet been recorded from the tropical Atlantic. Neither species has previously been recorded from the northtemperate Atlantic.

The same area was re-examined by H.M.S. Challenger towards the end of May, and in the interval the total plankton had decreased and only a few siphonophores were taken, with some Salpa fusiformis. However, at $47^{\circ} 40^{\prime} \mathrm{N}$., $13^{\circ} 58^{\prime} \mathrm{W}$. on 26 May, i.e. only a few miles from the earlier station referred to, a specimen of a very large Coscinodiscus type of diatom, $\mathrm{r} \cdot 8 \mathrm{~mm}$. in diameter, was taken. This was identified for me by Mr R. Ross of the British Museum (Natural History) as Ethmodiscus gazellae (Janisch) Hustedt, which is the largest diatom known and is recorded up to $\mathrm{r} \cdot 9 \mathrm{~mm}$. in diameter. He tells me that this species is widespread in tropical waters, being specially common in the Pacific, and that it has been recorded from the Mediterranean (Hustedt, I930, pp. 374-6) and from the Cape Verde Islands (Castracane, I886, as Ethmodiscus gigas). This is believed to be the first record of its presence in the north-east Atlantic. The specimen was in excellent condition and obviously alive when caught.

The abundance of 'Mediterranean' or 'Lusitanian' species in the plankton west of the British Isles has been remarkable in 1953, and will form the basis of a more detailed report elsewhere.

The specimens of Ritteriella picteti and $R$. amboinensis are being held at the Marine Laboratory, Aberdeen; the Ethmodiscus gazellae is deposited with the British Museum.

\section{REFERENCES}

CASTRACANe, F., I886. Report on the Diatomaceae collected by H.M.S. Challenger during the years 1873-1876. Rep. Sci. Res. Voy. H.M.S. 'Challenger', Bot., Vol. 2, $178 \mathrm{pp}$.

Hustedt, F., I930. Die Kieselalgen. Rabenhorst's Kryptogamen-Floravon Deutschland, Österreich und der Schweiz, Bd. 7. 920 pp.

Thompson, H., I948. Pelagic Tunicates of Australia. 196 pp. Melbourne. Council for Sci. Ind. Res. Australia. 